\title{
Changes in plant community and soil ecological indicators in response to Prosopis juliflora and Acacia mearnsii invasion and removal in two biodiversity hotspots in Southern India
}

\author{
Rajasekaran Murugan ${ }^{1,{ }^{*}}$, Francesca Beggi ${ }^{2}$, Nehru Prabakaran ${ }^{3,}$, Shafique Maqsood ${ }^{4}$, \\ Rainer Georg Joergensen ${ }^{1}$ \\ 1 Soil Biology and Plant Nutrition, University of Kassel, Nordbahnhof Str. 1a, 37213 Witzenhausen, Germany \\ 2 Bioversity International, India-Regional Office, College of Horticulture, GKVK campus, 560065 Bangalore, India \\ 3 Indo American Wildlife Society, 603211 Chennai, Tamil Nadu, India \\ 4 Soil Science, University of Kassel, Nordbahnhof Str. 1a, 37213 Witzenhausen, Germany
}

\section{A R TICLE I NFO}

\section{Article history:}

Received August 22, 2019

Revised October 6, 2019

Accepted October 22, 2019

\section{Keywords:}

Biodiversity

Enzyme activities

Invasive plant species

Metabolic quotient

Restoration

\begin{abstract}
A B S T R A C T
Invasion of alien plant species can alter local plant diversity and ecosystem processes closely linked to soil organic carbon (SOC) and nutrient dynamics. Soil ecosystem processes such as microbial respiration and enzyme activity have been poorly explored under alien plant invasion and especially following invasive plant species removal. We studied the impact of Prosopis juliflora and Acacia mearnsii invasion and subsequent removal on local plant community composition and diversity and on soil microbial respiration and enzyme activity in two biodiversity hotspots in Southern India. Removal of Prosopis promoted recolonisation of local vegetation as indicated by a $38 \%$ and $28 \%$ increase in species richness and ground vegetation cover, respectively, compared to an unremoved site. Prosopis and Acacia removal led to a significant reduction in soil microbial biomass $C(M B C)$, respiration, dehydrogenase and urease activity due to increased microbial respiration and $\mathrm{N}$ mineralisation rate. Higher metabolic quotients $\mathrm{qCO}_{2}$ in soil at Prosopis and Acacia removed sites indicate that MBC pools declined at a faster rate than $\mathrm{SOC}$, resulting decreased $\mathrm{MBC} / \mathrm{SOC}$ ratios compared to their respective removed sites. Natural and undisturbed ecosystems maintain more SOC through increased belowground and aboveground $\mathrm{C}$ input in the soil, resulting in a higher MBC content per unit SOC. Our results indicate that the interaction between above- and below-ground communities is a critical factor determining the structure and dynamics of local plant communities, especially in ecosystems affected by plant invasions.
\end{abstract}

(C) Higher Education Press 2019

\footnotetext{
* Corresponding author

E-mail address: raja.murugan15@gmail.com (R. Murugan)

†Present address: Wildlife Institute of India, Chandrabani, 248001

Dehradun, India
}

\section{Introduction}

The number of invasive plant species has been increasing (van Kluenen et al., 2015) and this poses a major threat to biodiversity, ecosystem processes and human livelihood 
worldwide (Inderjit and van der Putten, 2010; Pyšek et al., 2012). The most evident effect of plant invasions is the loss of local plant community composition and diversity (Callaway and Aschehoug, 2000; Cutway, 2017) through different mechanisms such as competition for limited resources, exploitation of resources untapped by local vegetation, novel chemical compounds and biotic interactions (Levine et al., 2003; Pyšek et al., 2012, Lorenzo et al., 2013). Loss of native diversity and domination of invasive plant species have been found to reduce provisioning and regulating ecosystem services, such as water provision, wildfire regulation, plant biodiversity and soil stabilization (Callaway and Aschehoug, 2000; Pyšek et al., 2012; Inderjit et al., 2017). Different mechanisms by which invasive plant species influence aboveground vegetation have been studied in detail (Simberloff et al., 2013; Inderjit et al., 2017) but the related below-ground ecosystem processes are still poorly understood.

Invasive plant species disrupt the critical link to belowground processes by affecting aboveground plant diversity. This may affect soil organic matter (SOM) due to changes in the quality and quantity of litter inputs (Ehrenfeld, 2010; Kaur et al., 2012), labile nutrient pools and by altering the rhizosphere dynamics typical of the local vegetation (Sharma and Raghubanshi, 2009; Inderjit and Cahill, 2015). In addition, invasive plant species can directly modify soil physical, chemical, and biological properties (Pyšek et al., 2012, Lorenzo et al., 2013; Inderjit and Cahill, 2015). To facilitate further invasion by conspecifics (Inderjit and van der Putten, 2010), invasive plants can increase litter decomposition, and nutrient mineralisation rates, which in turn can decrease overall SOC.

The important link between plant composition, growth, and SOM is based on the activity of soil microorganisms, which supply plant available nutrients through decomposition processes (Inderjit and van der Putten, 2010; Sinsabaugh et al., 2017). These decomposition processes and subsequent nutrient and $\mathrm{C}$ cycling are governed by the activity of microbial enzymes such as dehydrogenase and urease (Burns et al., 2013; Inderjit and Cahill, 2015). The activity of these two enzymes usually correlates with decomposition rate and subsequent $\mathrm{C}$ and $\mathrm{N}$ mineralisation rate (Burns et al., 2013; Sinsabaugh et al., 2017). Microbial biomass and activity (e.g. respiration) indices are more sensitive to environmental disturbance, such as plant invasions, than physio-chemical ones (Anderson and Domsch, 1993; Strickland et al., 2011; Inderjit and Cahill, 2015). This makes these microbial properties applicable and widely used to assess the impact of environmental disturbance on soil quality (Anderson and Domsch, 2010; Inderjit and Cahill, 2015). Microbial biomass C (MBC), basal respiration and the metabolic quotient- $q \mathrm{CO}_{2}$ (Anderson and Domsch, 1993, 2010), i.e. ratio of basal respiration to $\mathrm{MBC}$, are frequently used as soil ecological indicators (Murugan et al., 2014a; Goenster et al., 2017). The $q \mathrm{CO}_{2}$ values give information on the catabolic requirements of a microbial community for a certain period and serve as an indirect measure for microbial substrate use efficiency
(Anderson and Domsch, 2010; Sinsabaugh et al., 2017; Wardle and Ghani, 2018). However, combined information on how invasive plant species influence plant community composition and soil ecological indicators is scarce, especially in tropical ecosystems.

Prosopis juliflora and Acacia mearnsii (hereafter referred to as Prosopis and Acacia) are leguminous species originating from Mexico and Australia, respectively, and they are known as two of the most aggressive invasive plant species in the world. They were introduced to India in 1877 (Kaur et al., 2012) and 1861 (Joshi et al., 2018), respectively, for wood production and as a source of tannins in the leather industry. Prosopis and Acacia invaded a wide range of environments and became one of the dominant land covers at Point Calimere Wildlife Sanctuary, a Ramsar site and in the "Shola grasslands" ecosystem in Nilgiri Biosphere Reserve, respectively (Arasumani et al., 2018). Complete removal is considered an effective way to reduce the density of invasive populations and restore ecosystem services, including recovery of native biodiversity (Love et al., 2009; Simberloff et al., 2013), habitat provision and restoration of soil properties (Marchante et al., 2008; Strickland et al., 2011). However, invasive plant species removal programs have potential undesirable ecological effects such as soil erosion and further loss of biodiversity (Courchamp et al., 2011; van der Waal et al., 2012) and should therefore be evaluated at the species and landscape level (Inderjit et al., 2017). Current knowledge on the effects of removal on plant and soil communities is limited, especially in tropical ecosystems (Cutway, 2017; Inderjit et al., 2017; Arasumani et al., 2018).

The aim of our work is to assess the impact of Prosopis and Acacia invasion and subsequent removal on local plant community composition and soil ecological indicators in two biodiversity hotspots. We hypothesised that invasive plant species removal would facilitate restoration of local vegetation at the expense of $\mathrm{C}$ and $\mathrm{N}$ pools through decreased plant $\mathrm{C}$ input. More specifically, we tested the following hypotheses: (i) The presence of invasive plant species changes local plant community composition and decreases its diversity and ground vegetation cover due to increased competition for resources. (ii) Removal of invasive plant species promotes the recovery of local plant community. (iii) The stress derived by plant invasion and removal decreases SOC, total N, MBC, and microbial biomass $\mathrm{N}$ (MBN) contents. (iv) Plant invasion and removal induced changes in soil $\mathrm{C}$ and $\mathrm{N}$ contents consequently reduces basal respiration as well as dehydrogenase and urease activities, but increases $q \mathrm{CO}_{2}$ values.

\section{Materials and methods}

\subsection{Site characteristics}

The invasive species Prosopis was studied in the Point Calimere Wildlife Sanctuary (hereafter "Point Calimere," $10.2942^{\circ} \mathrm{N}, 79.8579^{\circ} \mathrm{E}, 2-5 \mathrm{~m}$ asl) on the south-eastern coast of India. The site is characterised by a mosaic of 
vegetation interspersed on a coastal grassland plain that seasonally floods due to the north-east monsoon (November to December) and remains underwater from November to February. Flood water recedes from January onwards leaving the grassland plain exposed by April to May. Thick woodland vegetation typical of tropical dry evergreen forests occurs on slightly elevated patches amidst the floodplains. The soil is classified as Vertisols with clayey sand texture derived from deltaic alluvium. Mean annual temperature is $29.5^{\circ} \mathrm{C}$ and the mean annual precipitation is $1250 \mathrm{~mm}$. Prosopis is the single most dominant invasive species in Point Calimere, where it colonised vast grassland habitats critical for the survival of unique wildlife (Baskaran et al., 2016). Prosopis plants range from 30 to 50 years of age based on a cumulative girth size (cumulative circumference at $1.3 \mathrm{~m}$ height) of $3 \mathrm{~m}$. The State Forest Department of Tamil Nadu has started to remove 15 ha of Prosopis at Point Calimere in May 2015 as a part of the "Biodiversity and Greening Project."

In this study, we examined three treatments: (i) Prosopis removed site (PRS) - all Prosopis individuals were completely uprooted (i.e., each Prosopis individuals were cut and uprooted by manually) in May 2015. These sites are usually grasslands or fringes of woodland vegetation with sparsely distributed stunted native trees such as Salvadora persica and Dichrostachys cinerea. (ii) Prosopis unremoved site (PUS) - a dense vegetation of Prosopis in the seasonal floodplains fringing the native woodland vegetation adjacent to the Prosopis removal sites. The ground layer is usually under a dense canopy and often devoid of any ground vegetation. (iii) Control site (CS) - characterised by the local vegetation, i.e., tropical dry evergreen forest (average canopy height $5 \mathrm{~m}$ ) patches amidst the seasonal flood plains with sparsely distributed large trees (i.e., Manilkara hexandra, Lannea coromendalica, Cassia fistula) that can reach up to 15 $\mathrm{m}$ canopy height. Each treatment was represented by three equal plots (replicates) of $100 \mathrm{~m}^{2}(10 \mathrm{~m} \times 10 \mathrm{~m})$ randomly chosen with minimum $100 \mathrm{~m}$ distance from each other, resulting in a total of 3 plots per treatment. Species removal plots were established within an area of the invasive species in which unremoval plots were randomly established within a total area of 16 ha, where control plots represented the gap areas within the area of the invasive species.

The second invasive species, Acacia, was studied in the Mandhu Shola forest at Parsons Valley, which is located in the Western Ghats biodiversity hotspot, south of the Nilgiri Biosphere Reserve (hereafter Nilgiri) in Tamil Nadu, India $\left(11.3707^{\circ} \mathrm{N}, 76.5858^{\circ} \mathrm{E}, 2250 \mathrm{~m}\right.$ asl). The vegetation in the study area consists of patches of stunted tropical evergreen forests (locally called "shola") surrounded by vast grasslands, hence the name "Shola grasslands." Grasslands are usually situated on the mountains while woodlands are found in the valleys (Fig. 1). The soils are classified as non-allophanic Andisols with clay-loam texture derived from gneiss and schist (Caner et al., 2007). Mean annual temperature is $15^{\circ} \mathrm{C}$, with frost temperatures during December-January and mean annual precipitation is $3750 \mathrm{~mm}$, ranging from 3000 to
$4500 \mathrm{~mm}$ (Caner et al., 2007).

Here we examined two treatments: (i) Acacia removed site (ARS) - the entire Acacia population was removed in May 2015 and nearly $50 \%$ of the land was covered by herbaceous grasses while the rest of the land remained bare. Removal was primarily done by manual cutting, leaving the rootstock in the soil (Acacia did not coppice - Prabakaran, personal observation). (ii) Acacia unremoved site (AUS) - thick impenetrable woody vegetation of Acacia with sparsely distributed native shrubs and mostly covered by grasses and mosses. Three equal plots (replicates) of $100 \mathrm{~m}^{2}(10 \mathrm{~m} \times$ $10 \mathrm{~m}$ ) for each treatment were randomly selected $(\min 100 \mathrm{~m}$ distance) within an area of 4 ha (2230-2270 m asl).

\subsection{Vegetation data collection and plant diversity indices}

The data were collected using a nested sampling design following the protocol of Peet et al. (1998) (Fig. 2). In April 2016 , all trees with girth size at breast height $(\mathrm{GBH})>10 \mathrm{~cm}$ were enumerated in each plot. Within each plot, four subplots of $3 \mathrm{~m} \times 3 \mathrm{~m}$ (one at each corner) were used to enumerate saplings and shrubs $(1 \mathrm{~cm}<\mathrm{GBH}<10 \mathrm{~cm})$, resulting in a total of 12 subplots per treatment with a total combined area of $108 \mathrm{~m}^{2}$. Similarly, herbs, grasses and seedlings $(<1.3 \mathrm{~m}$ height), jointly referred to as ground vegetation, were enumerated in nested subplots of $1 \mathrm{~m} \times 1 \mathrm{~m}$ established at each corner of the subplots.

To describe the plant communities in our two locations, we used four parameters: (i) ground vegetation cover and composition; (ii) plant species richness; (iii) the Shannon index $(H)$ and (iv) Simpson reciprocal index (1/D). Ground vegetation cover (\%) was calculated through direct estimation according to Daubenmire (1959), while ground vegetation composition was assessed through species presence/ absence matrices and by Jaccard similarity index (Table 1). Plant species richness was calculated as the sum of the number of species encountered in the three plots of each treatment for each functional group in the community (grasses, herbs, shrubs, seedlings, saplings and trees, Nehru and Balasubramanium, 2014). The relative proportion (\%) of species in each functional group (Fig. 3 ) is hereafter referred to as plant functional groups composition. Prosopis and Acacia were not included in the species counts. Plant diversity was measured in each plot and functional group using the Shannon index and the Simpson reciprocal index.

\subsection{Soil sampling and analysis}

Soil samples were taken in April 2016 from each plot. Samples were collected from ten sampling points along a $z$ shaped trajectory at $0-10 \mathrm{~cm}$ depth and pooled to obtain four representative samples per plot, resulting in 12 samples per treatment. Soil samples were sieved $(<2 \mathrm{~mm})$ to remove visible roots and litter material and stored at $4^{\circ} \mathrm{C}$ until analysis. Soil water content was determined by oven drying to a constant mass at $105^{\circ} \mathrm{C}$. Total $\mathrm{C}$ and $\mathrm{N}$ were determined using an elemental analyzer, while soil $\mathrm{pH}$ was determined using a 

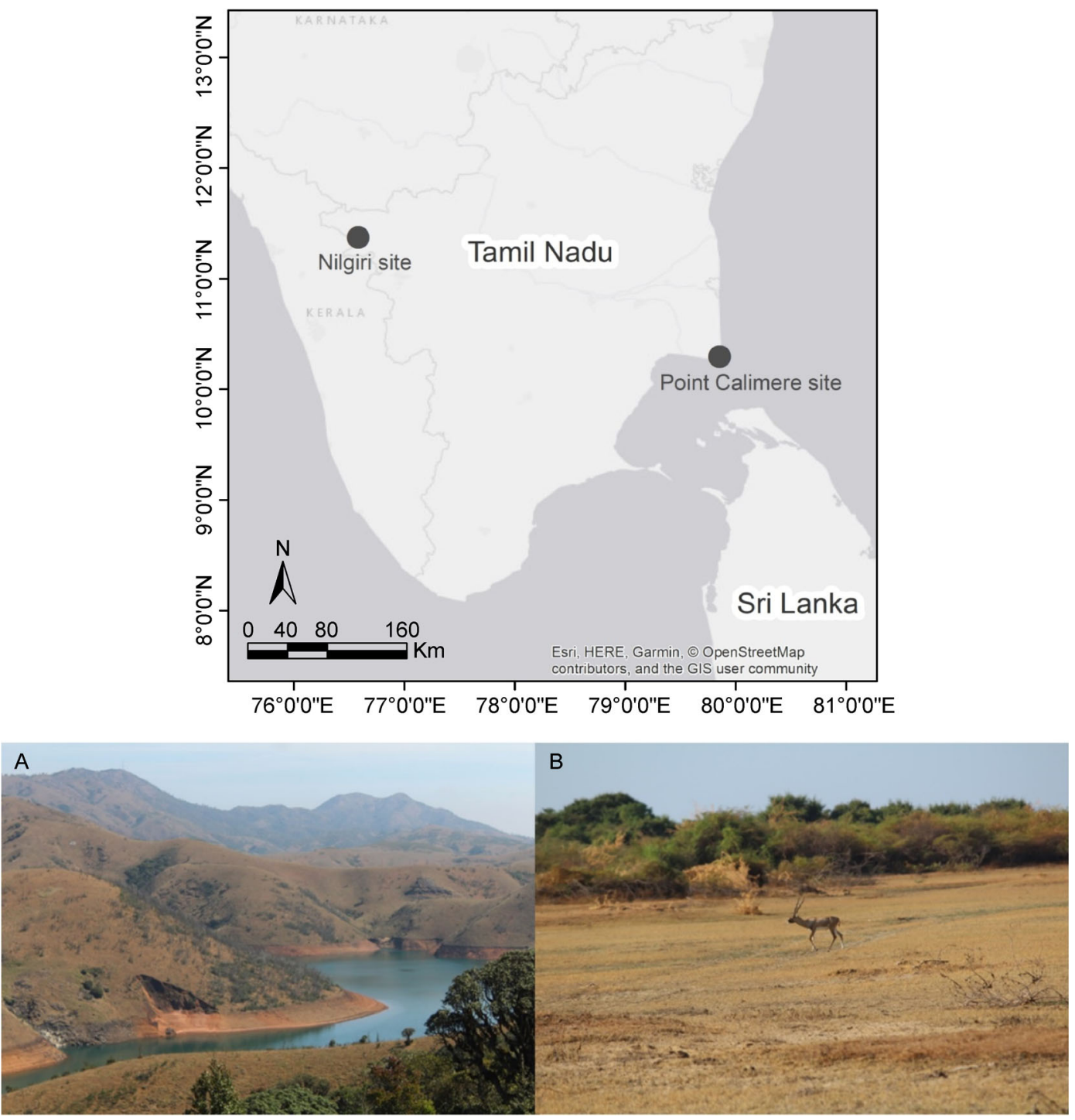

Fig. 1 Location of the study sites in South Indian state Tamil Nadu. (A) Panorama of the Shola grasslands indicating Acacia invasion at hill slopes in the Nilgiri Biosphere Reserve. (B) Prosopis removed site with abundant ground vegetation, which is the main source of survival for the endangered black buck at Point Calimere Wildlife Sanctuary. Map indicating the study locations.

Table 1 PERMANOVA results based on Jaccard dissimilarities using site wise species presence/absence matrix of ground vegetation (i.e., herbs, grasses, seedlings) between treatments: Prosopis removed site (PRS) vs Prosopis unremoved site (PUS) in Point Calimere and Acacia removed sites (ARS) vs Acacia unremoved sites (AUS) in Nilgiri.

\begin{tabular}{llllllll}
\hline Study location & Data type & $\mathrm{df}$ & SS & MS & Pseudo F & $R^{2}$ & $P$ \\
\hline Point Calimere & PRS vs PUS & 1 & 0.7116 & 0.71158 & 1.9236 & 0.0804 & 0.0196 \\
& Residuals & 22 & 8.1384 & 0.36993 & & 1 & 0.1110 \\
\multirow{4}{*}{ Nilgiri } & Total & 23 & 8.8500 & & & 0.007 \\
& ARS vs AUS & 1 & 0.8108 & 0.81080 & 2.7478 & 0.8889 \\
& Residuals & 22 & 6.4915 & 0.29507 & & 1 & \\
& Total & 23 & 7.3023 & & & & \\
& & &
\end{tabular}




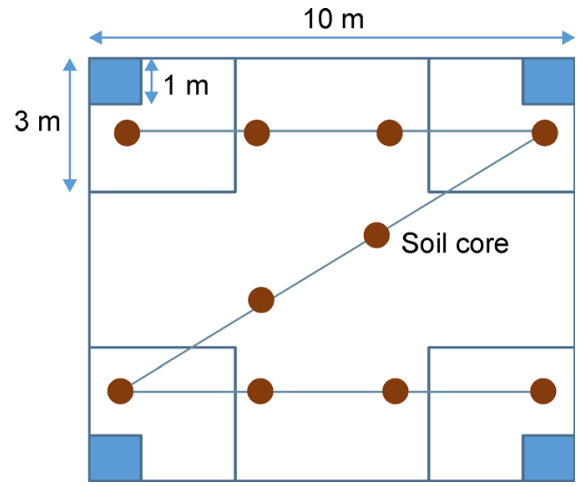

Fig. 2 Design of the sample plot used in the study. At each treatment, three equal plots of $100 \mathrm{~m}^{2}(10 \mathrm{~m} \times 10 \mathrm{~m})$ were randomly specified at $100 \mathrm{~m}$ distance to each other. Trees were enumerated in each plots $(10 \mathrm{~m} \times 10 \mathrm{~m})$, saplings and shrubs were enumerated in four nested subplots $(3 \mathrm{~m} \times 3 \mathrm{~m})$ established at each corner of the plot. Herbs, grasses and seedlings were enumerated within four nested subplots $(1 \mathrm{~m} \times 1 \mathrm{~m})$. Ten soil samples were collected in each plot and pooled to make representative sample per plot.

$\mathrm{pH}$ meter after shaking a soil-water (1 to 2.5 ratio) suspension for $30 \mathrm{~min}$.

\subsection{Net $\mathrm{N}$ mineralisation}

Debris free (to avoid immobilisation) fresh soil samples (10 g) were incubated at their respective mean annual temperature for 30 days to determine net $\mathrm{N}$ mineralisation rate. Soil samples $(5 \mathrm{~g})$ were extracted with $25 \mathrm{~mL} 0.1 \mathrm{M} \mathrm{KCl}$ for $2 \mathrm{~h}$ at $180 \mathrm{rev} \mathrm{min}^{-1}$. The extracts were filtered to obtain a clear extract (Schleicher and Schuell No. 2095 1/2). Extracts were analysed for concentrations of dissolved inorganic $\mathrm{N}\left(\mathrm{NH}_{4}{ }^{+}+\right.$ $\mathrm{NO}_{3}{ }^{-}$) by a continuous flow auto-analyzer. Net $\mathrm{N}$ mineralisation was calculated as the differences in dissolved inorganic $\mathrm{N}$ between 0 and 30 days after incubation.

\subsection{Soil microbial biomass}

Soil $\mathrm{MBC}$ and $\mathrm{MBN}$ were determined by fumigation extraction (Brookes et al., 1985; Vance et al., 1987). Fumigated (24 h) with ethanol-free $\mathrm{CHCl}_{3}$ at $25^{\circ} \mathrm{C}$ and non-fumigated $5 \mathrm{~g}$ fresh soil samples were extracted with $20 \mathrm{~mL}$ of $0.5 \mathrm{M} \mathrm{K}_{2} \mathrm{SO}_{4}$ by 30 min horizontal shaking at $200 \mathrm{rev} \mathrm{min}^{-1}$ and filtered (hw3, Sartorius Stedim Biotech). Organic $\mathrm{C}$ and total $\mathrm{N}$ in the extracts were determined using a multi N/C 2100 S automatic analyzer (Analytik Jena, Germany). Soil MBC was calculated as $E_{\mathrm{C}} / k_{\mathrm{EC}}$, where $E_{\mathrm{C}}=$ (organic $\mathrm{C}$ extracted from fumigated soil) - (organic $\mathrm{C}$ extracted from non-fumigated soil) and $k_{\mathrm{EC}}$ $=0.45\left(\mathrm{Wu}\right.$ et al., 1990). MBN was calculated as $E_{N} / k_{\mathrm{EN}}$, where $E_{\mathrm{N}}=$ (total $\mathrm{N}$ extracted from fumigated soil) - (total $\mathrm{N}$ extracted from non-fumigated soil) and $k_{\mathrm{EN}}=0.54$ (Brookes et al., 1985). The $\mathrm{C}$ and $\mathrm{N}$ content in $\mathrm{K}_{2} \mathrm{SO}_{4}$ extracts from respective soil samples without $\mathrm{CHCl}_{3}$ fumigation are considered as extractable organic $\mathrm{C}$ (EOC) and N (EON), respectively (Beck et al., 1997).

\subsection{Microbial respiration and enzyme activity}

Basal respiration was measured by incubating a $60 \mathrm{~g}$ soil sample for seven days at $22^{\circ} \mathrm{C}$ and $40 \% \mathrm{WHC}$. The emitted $\mathrm{CO}_{2}$ was trapped in $0.5 \mathrm{M} \mathrm{NaOH}$ and the excess $\mathrm{NaOH}$ was back titrated using $0.5 \mathrm{M} \mathrm{HCl}$ after the adding saturated $\mathrm{BaCl}_{2}$ solution and phenolphthalein as indicator. The respiration rate per unit MBC termed as metabolic quotient $\left(q \mathrm{CO}_{2}\right)$.

Dehydrogenase and urease activities were determined in duplicate soil samples collected from each treatment plot. Briefly, dehydrogenase activity was quantified by determining the concentration of triphenyl formazan (TPF) produced after incubation of soil samples ( $1 \mathrm{~g}$ each) with triphenyltetrazolium chloride for $24 \mathrm{~h}$ at $30^{\circ} \mathrm{C}$. The intensity of the red color was measured at $485 \mathrm{~nm}$. Dehydrogenase activity was expressed as $\mu \mathrm{g}$ of TPF formed per gram of sample per $24 \mathrm{~h}$ (Casida et al., 1964). Urease activity was determined as the amount of ammonia released after incubation of soil samples (5 $\mathrm{g}$ each)

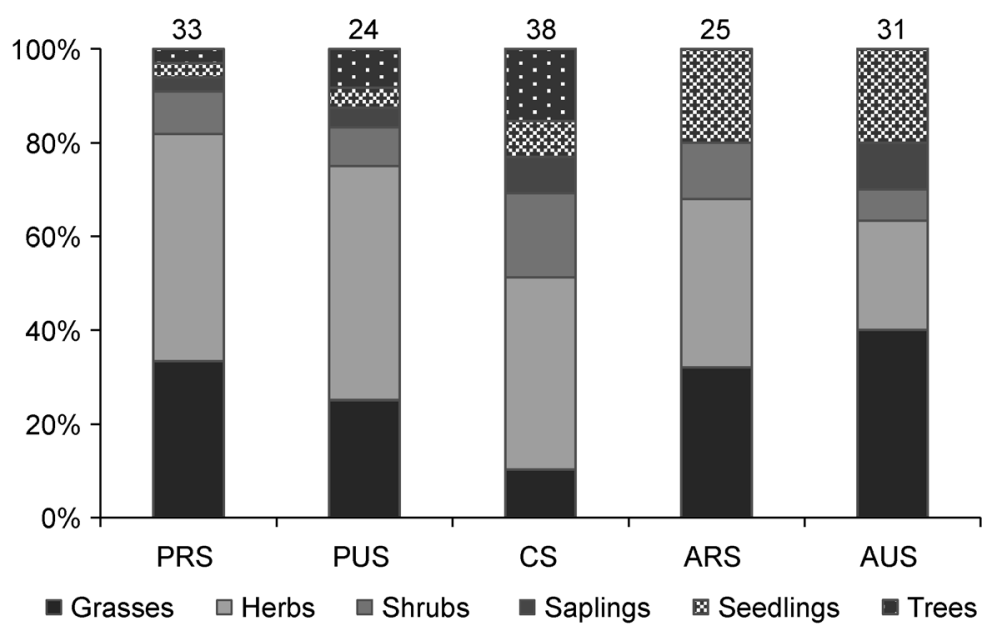

Fig. 3 Functional groups composition (bars), mean ground cover (\%) and plant species richness (values on top of each bar) in Prosopis and Acacia removed (PRS, ARS), unremoved (PUS, AUS) sites and Control site (CS) sites at Point Calimere. 
with urea for $2 \mathrm{~h}$ at $37^{\circ} \mathrm{C}$ (Kandeler and Gerber, 1988).

\subsection{Statistical analysis}

We used Permutational Multivariate Analysis of Variance (PERMANOVA) based on Jaccard distance matrices to assess differences in ground vegetation composition across treatments. The analysis was conducted using the adonis function from the $R$ package vegan. Differences in soil parameters among treatments were assessed through oneway ANOVA and Student's $t$-test $(P<0.05)$ when residuals were normally distributed and variances homogeneous. Whenever these assumptions were not met, the nonparametric Kruskall-Wallis test (Point Calimere location) and the Wilcoxon test (Nilgiri location) were used to assess treatment effects on measured soil quality parameters. Multiple comparisons across subgroups were carried out using Dunn's test $(P<0.05)$. All statistical analyses were performed with $\mathrm{R}$ (ver. 3.5.1).

\section{Results}

\subsection{Plant community composition and diversity}

Removal of Prosopis increased the mean ground vegetation cover and species richness, especially of grasses by $28 \%$ and $38 \%$ respectively (Fig. 3). Species richness was 63 and $18 \%$ higher at CS compared to PUS and PRS, respectively (Fig. 3). In contrast, removal of Acacia decreased mean ground vegetation cover and species richness by $24 \%$, with the exception of herbs and shrubs, whose diversity increased by $59 \%$ and $86 \%$, respectively (Fig. 3). Species composition of ground vegetation differed significantly between the removed and unremoved sites of both Prosopis and Acacia (PERMANOVA $P<0.05$, Table 1 ).

The Shannon diversity index highlighted that local plant community diversity was highest at Control site and decreased in the order of Control site (3.0) > Prosopis removed site (1.6)> Prosopis unremoved site (1.1). The Shannon index was higher at Acacia removed site (1.9) than Acacia unremoved site (1.7). The Simpson index followed the same pattern at both study sites. Prosopis invasion caused a dramatic drop in plant diversity of all functional groups (Supplementary Table 1), while herbs diversity and grass species richness increased after removal (not presented). The same increase in herbs diversity but not in grass species richness was observed at Nilgiri (Supplementary Table 2). Seedlings diversity was zero in Point Calimere and was higher at unremoved sites as compared to removed sites in Nilgiri.

\subsection{SOC dynamics}

In both Point Calimere and Nilgiri, soil pH was significantly lower at the removed sites. Water content was significantly higher at PUS than at PRS, while it was higher at ARS than at AUS. Contents of SOC and MBC as well as basal respiration were lowest at Prosopis removed sites and increased in the order of Prosopis removed site < Prosopis unremoved site < Control site. Similarly, MBC and basal respiration were 44 and $14 \%$ lower at ARS compared to AUS. In contrast, PRS and ARS had 39 and $16 \%$ higher concentrations of EOC compared to their respective unremoved sites (Table 2).

\subsection{Soil N dynamics}

The concentration of total $\mathrm{N}$ was highest at Control site and decreased in the order of CS > PUS > PRS, while MBN was highest at PUS, although not significantly different from other treatments. In contrast, the concentration of EON and the $\mathrm{N}$ mineralisation rate were significantly higher at PRS and decreased in order of PRS $>$ CS $>$ PUS (Table 3). Similarly, removal of Acacia increased $\mathrm{EON}$ concentration and $\mathrm{N}$ mineralisation rate (by 8 and $32 \%$, respectively) and decreased total $\mathrm{N}$ and MBN concentration (by 17 and $31 \%$, respectively) in comparison with AUS, although differences in EON and total $\mathrm{N}$ concentrations were not significant.

\subsection{Enzyme activities}

Dehydrogenase (Fig. 4A) and urease (Fig. 4B) activities were more than $50 \%$ lower in Point Calimere than in Nilgiri and decreased significantly (by about $25 \%$ ) after removal of both Acacia and Prosopis. More specifically, for Prosopis dehydrogenase activity decreased in the order CS $>$ PUS $>$ PRS. For Acacia, dehydrogenase activity was higher at AUS than at ARS. Urease activity was lowest at PRS and increased in the

Table 2 Mean values of soil $\mathrm{pH}$, water content (WC), concentrations of extractable organic $\mathrm{C}(\mathrm{EOC})$, soil organic $\mathrm{C}$ (SOC), microbial biomass $\mathrm{C}$ (MBC) and soil respiration activity $\left(\mathrm{CO}_{2}-\mathrm{C}\right)$ in different treatments and study locations.

\begin{tabular}{|c|c|c|c|c|c|c|c|}
\hline Study location & Treatment & $\mathrm{pH}$ & WC (\%) & $\mathrm{EOC}\left(\mu \mathrm{g} \mathrm{g}^{-1}\right)$ & SOC $\left(\mathrm{mg} \mathrm{g}^{-1}\right)$ & $\mathrm{MBC}\left(\mu \mathrm{g} \mathrm{g}^{-1}\right)$ & $\mathrm{CO}_{2}-\mathrm{C}\left(\mu \mathrm{g} \mathrm{CO}_{2}-\mathrm{C} \mathrm{g}^{-1} \mathrm{~h}^{-1}\right)$ \\
\hline \multirow[t]{3}{*}{ Point Calimere } & PRS & $5.3 \mathrm{a}$ & $23 a$ & $486 \mathrm{a}$ & $6.7 \mathrm{a}$ & $231 \mathrm{a}$ & $14 \mathrm{a}$ \\
\hline & PUS & $6.2 \mathrm{~b}$ & $36 \mathrm{~b}$ & $349 a$ & $7.9 \mathrm{~b}$ & $292 b$ & $16 b$ \\
\hline & CS & $5.9 \mathrm{~b}$ & $40 \mathrm{~b}$ & $545 a$ & $10.0 \mathrm{c}$ & $403 c$ & $19 \mathrm{c}$ \\
\hline$P$ values & & $<0.01$ & 0.01 & 0.17 & $<0.01$ & $<0.01$ & $<0.01$ \\
\hline \multirow[t]{2}{*}{ Nilgiri } & ARS & $4.2 \mathrm{a}$ & 17 b00, & $1979 a$ & $119 a$ & $1168 \mathrm{a}$ & $29 a$ \\
\hline & AUS & $4.4 \mathrm{~b}$ & 12 a.25 & $1705 a$ & $142 \mathrm{a}$ & $2078 b$ & $34 \mathrm{~b}$ \\
\hline$P$ values & & 0.02 & 0.02 & 0.16 & 0.35 & $<0.01$ & 0.05 \\
\hline
\end{tabular}

Different letters within a column indicate a factor-specific significant difference between treatments (Prosopis removed site - PRS; Prosopis unremoved site - PUS; Control site - CS) in Point Calimere Wildlife Sanctuary (Point Calimere; Dunn test, $P<0.05$ ) and between $A$ cacia removed sites (ARS) and Acacia unremoved sites (AUS) in Nilgiri Biosphere Reserve (Nilgiri; Wilcoxon test, $P<0.05$ ). 
Table 3 Mean concentrations of extractable organic $\mathrm{N}(\mathrm{EON})$, total $\mathrm{N}$, microbial biomass $\mathrm{N}(\mathrm{MBN}), \mathrm{N}$ mineralisation rate (NMR) and soil C/N ratio in different treatments and study locations.

\begin{tabular}{lllllll}
\hline Study location & Treatment & EON $\left(\mu \mathrm{g} \mathrm{g}^{-1}\right)$ & Total N $\left(\mathrm{mg} \mathrm{g}^{-1}\right)$ & MBN $\left(\mu \mathrm{g} \mathrm{g}^{-1}\right)$ & $\left.\mathrm{NMR}_{\left(\mu \mathrm{g} \mathrm{g}^{-1} \mathrm{~d}^{-1}\right)}{\mathrm{Soil} \mathrm{C} / \mathrm{N}^{-}(\mu \mathrm{g} \mathrm{g}}^{-1}\right)$ \\
\hline Point Calimere & PRS & $106 \mathrm{c}$ & $0.62 \mathrm{a}$ & $34 \mathrm{a}$ & $14 \mathrm{~b}$ & $11.0 \mathrm{~b}$ \\
& PUS & $057 \mathrm{a}$ & $0.76 \mathrm{~b}$ & $52 \mathrm{a}$ & $08 \mathrm{a}$ & $10.4 \mathrm{a}$ \\
& $\mathrm{CS}$ & $089 \mathrm{~b}$ & $1.03 \mathrm{c}$ & $42 \mathrm{a}$ & $011 \mathrm{ab}$ & $10.8 \mathrm{~b}$ \\
$P$ values & & 0.01 & $<0.01$ & 0.16 & $<0.05$ & 0.05 \\
Nilgiri & ARS & $834 \mathrm{a}$ & $7.76 \mathrm{a}$ & $200 \mathrm{a}$ & $25 \mathrm{~b}$ & $15.4 \mathrm{a}$ \\
& AUS & $796 \mathrm{a}$ & $9.47 \mathrm{a}$ & $292 \mathrm{~b}$ & $19 \mathrm{a}$ & $15.1 \mathrm{a}$ \\
$P$ values & & 0.51 & 0.23 & $<0.01$ & 0.01 & 0.17 \\
\hline
\end{tabular}

Different letters within a column indicate a factor-specific significant difference between treatments (Prosopis removed site - PRS; Prosopis unremoved site - PUS; Control site - CS) in Point Calimere Wildlife Sanctuary (Point Calimere; Dunn test, $P<0.05$ ) and between Acacia removed sites (ARS) and Acacia unremoved sites (AUS) in Nilgiri Biosphere Reserve (Nilgiri; Wilcoxon test, $P<0.05$ ).
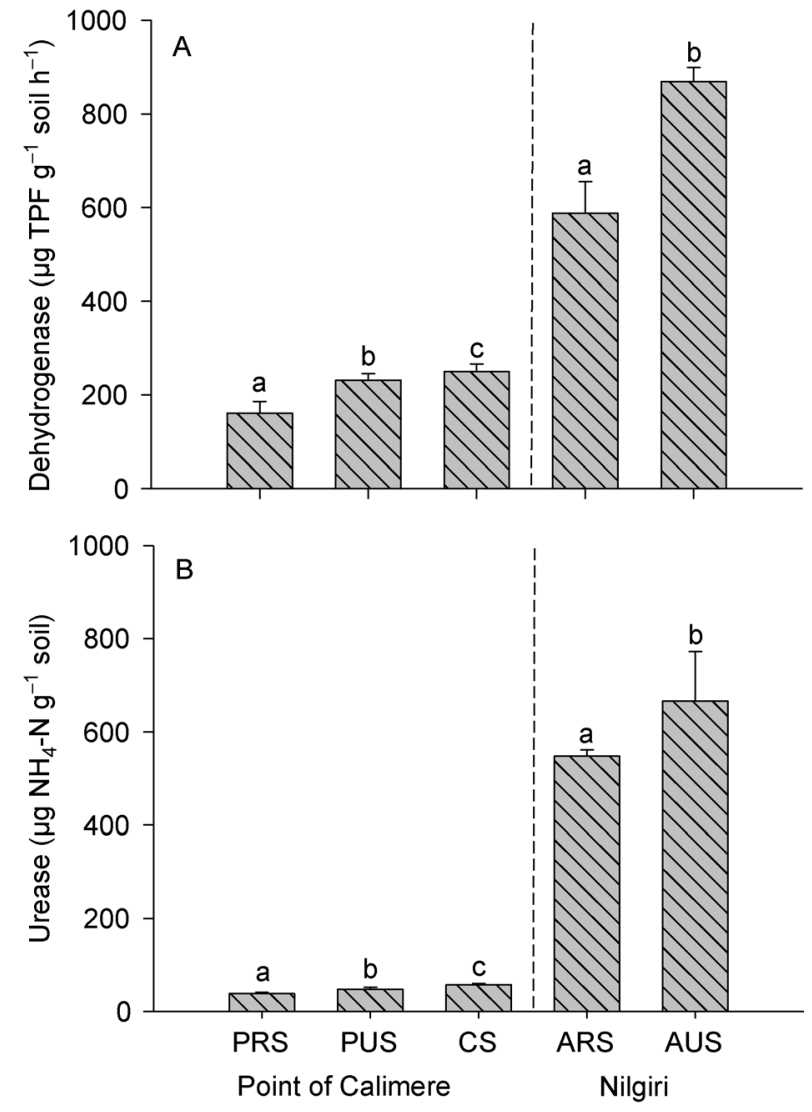

Fig. 4 Mean (A) dehydrogenase and (B) urease activity in soil among - Prosopis removed site (PRS), Prosopis unremoved site (PUS), Control site (CS) at Point Calimere (Dunn test, $P<0.05$ ), Acacia removed sites (ARS) and Acacia unremoved sites (AUS) at Nilgiri (Wilcoxon test, $P<0.05$ ). Different lowercase letters indicate significant differences between treatments at a given study location. Error bars show standard error of mean $(n=9)$.

order PRS $<$ PUS $<$ CS while it did not differ between ARS and AUS (Fig. 4B).

\subsection{Soil microbial indicators}

The lowest $\mathrm{MBC} / \mathrm{SOC}$ ratio was observed after removal of
Prosopis and Acacia and it increased in the order PRS < PUS $<$ CS and ARS < AUS (Fig. 5A). On the other hand, $q \mathrm{CO}_{2}$ showed an opposite trend with higher values at PRS and ARS and lower values at PUS and AUS (Fig. 5B). The MBC/MBN ratio showed different patterns in Point Calimere and Nilgiri (Fig. 5C). In Point Calimere, this ratio increased in the order of $\mathrm{PUS}<\mathrm{PRS}<\mathrm{CS}$. In contrast, in Nilgiri, the $\mathrm{MBC} / \mathrm{MBN}$ ratio was higher at AUS than at ARS. Values of $q \mathrm{CO}_{2}$ exhibited an inverse relationship with the MBC/SOC ratio $(r=-0.71$, $P<0.01, n=60)$ and a strong positive relationship with the soil $\mathrm{C} / \mathrm{N}$ ratio $(r=0.60, P<0.01, n=60)$.

\section{Discussion}

4.1 Local plant community response to invasive species invasion and removal

As expected, removal of invasive species altered the environmental conditions of the studied sites, due to soil mechanical disturbance, root ecosystem disruption, and changes in canopy that led to altered light exposure for plants and soil. These impacts are reflected by differences in species richness, diversity, composition and ground vegetation cover between the removed and unremoved sites. Changes in ground vegetation cover exhibited different patterns between Point Calimere and Nilgiri. A strong decline in plant diversity across all functional groups supports our first hypothesis that the presence of invasive plant species leads to a decrease in local plant species diversity, as indicated by the Shannon and Simpson indices. A loss of forest area and local species diversity, including plant and wild animals, was observed in Point Calimere in 1940s as consequence of an experiment designed to grow Prosopis for wood and tannin production (Ali, 2005).

Studies based on LANDSAT ETM images showed that the invasion of Prosopis led to a reduction in open grasslands (Baskaran et al., 2016). The loss of open grasslands is a major threat especially to the endangered blackbuck (Antelope cervicapra) in Point Calimere (Ali 2005; Baskaran et al., 2016). In addition, the invasion of Prosopis led to fragmentation of the tropical dry evergreen forest habitat and to a 

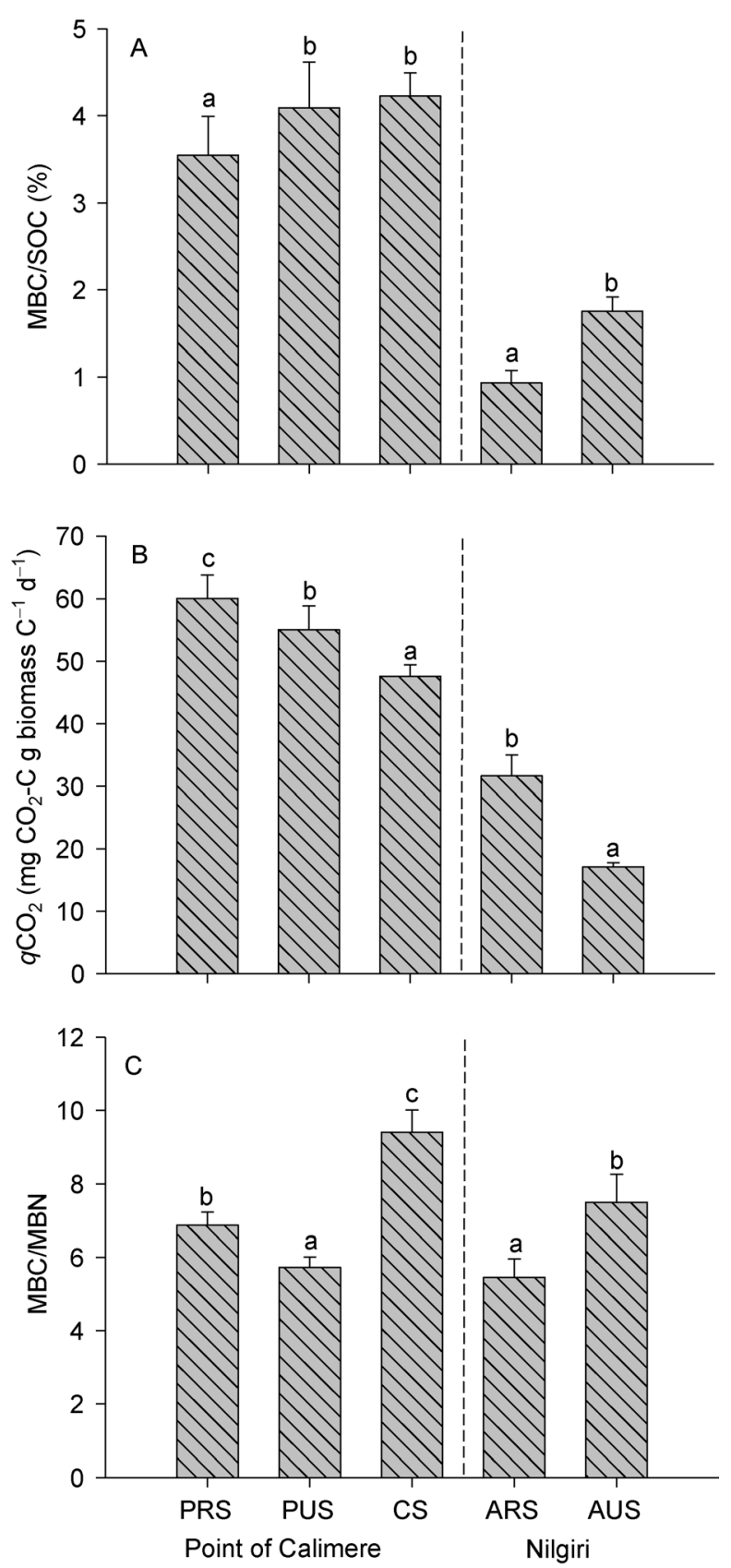

Fig. 5 Mean ratios of (A) MBC/SOC (\%), (B) metabolic quotient $q_{\mathrm{CO}_{2}}\left(\mathrm{mg} \mathrm{CO}_{2}-\mathrm{C} \mathrm{g}\right.$ microbial biomass $\mathrm{C}^{-1} \mathrm{~d}^{-1}$ ) and (C) $\mathrm{MBC} /$ MBN among different treatments - Prosopis removed site (PRS), Prosopis unremoved site (PUS), Control site (CS) at Point Calimere (Dunn test, $P<0.05$ ), Acacia removed sites (ARS) and Acacia unremoved sites (AUS) at Nilgiri (Wilcoxon test, $P$ $<0.05$ ). Different lowercase letters indicate significant differences between treatments at a given study location. Error bars show standard error of mean $(n=9)$.

subsequent $63 \%$ loss in native trees. As a result, the net primary productivity of the entire tropical dry evergreen forest decreased with the spread of Prosopis, reaching alarmingly low levels (Ali, 2005). Removal of Prosopis increased herb diversity and grass species richness, confirming our second hypothesis on the deleterious effects of Prosopis on local vegetation diversity. Removal of Prosopis population has been shown to facilitate the growth and establishment of neighboring plant species through the loss of allelopathic phenolic compounds in the litter, rhizosphere and bulk soil (Kaur et al., 2012).

In contrast to Prosopis sites, Acacia sites showed higher species richness and ground vegetation cover at the unremoved site compared to the removed site (Fig. 3). Contrary to Prosopis, Acacia trees were manually cut, leaving roots and stumps in the ground and allowing major tree parts to degrade on site, with the exception of large poles sent out as fuel wood. The bark of Acacia is a rich source of tannins and other phenolic compounds (Seigler, 2003). Therefore, the release of chemical compounds from the decaying Acacia trees into the soil may have contributed to the lower species richness observed, especially for grasses at the site where Acacia was removed. Further investigations on the effects of chemical compounds from decaying Acacia during plant succession are needed to verify this hypothesis. The relatively limited colonisation of grass species might also be attributed to increased soil disturbance caused by Acacia removal activities. Soil disturbance intensity is known to play a key role in plant succession following perturbations (Chazdon, 2003; Nehru and Balasubramanium, 2014).

Previous studies have suggested that $83 \%$ of the Shola grasslands on the Nilgiri plateau (Sukumar et al., 1995) and $66 \%$ in the Palani hills (Arasumani et al., 2018), further south from our study site, have been lost due to land use change and invasion of Acacia. Though the negative impacts of Acacia on native grasslands are well established, the scientific community is still sceptic about the complete removal of Acacia to restore grasslands (Arasumani et al., 2018; Joshi et al., 2018), largely due to unknown effects on above- and belowg-round communities (Marchante et al., 2008; Inderjit and Cahill, 2015). A better understanding of habitat responses to Acacia removal is needed and should be based on standardised long-term experimental settings. We recorded changes in species diversity only one year after the removal of both invasive species but long-term monitoring of these sites is critical to understand the legacy impacts of invasive species colonisation and removal on the recovery of local plant communities.

4.2 Microbial biomass and activity drive changes in soil $\mathrm{C}$ and $\mathrm{N}$ pools

Soil MBC accounts for only about $1.2 \%$ of SOC, but it is the most active component in driving organic matter decomposition and storage (Liang and Basler, 2011). In line with our third hypothesis, removal of invasive species and the subsequently lower $C$ input to soil led to a decline in the accumulation of SOC, total N, MBC, MBN, and microbial respiration. Loss of plant diversity can have important and diverse effects on soil properties, microclimate and microbial activity (Inderjit and van der Putten, 2010; Bardgett et al., 2013; Murugan et al., 2014b). In addition, plant canopy removal increases ground 
level radiation and soil evaporation rates, resulting in higher soil temperature and lower soil moisture content. This likely enhanced mineralisation, accelerated diffusion of soluble substrates in soil (Hagerty et al., 2014) at PRS. These changes in SOC and total $\mathrm{N}$ as well as $\mathrm{MBC}$ and $\mathrm{MBN}$ are also reflected in decreased dehydrogenase and urease activity rates, which confirms our third hypothesis.

Dehydrogenase $(r=0.95, P<0.01, n=60)$ and urease $(r=$ $0.79, P<0.01, n=60)$ activities were significantly correlated with basal respiration. A possible explanation is that the litter inputs not only provide energy for enzyme production but also increase microbial $\mathrm{C}$ demands, which are in turn expected to be alleviated by promoting enzyme activities, ultimately influencing microbial respiration (Stone et al., 2014). In addition, an increase in soil enzyme activity and microbial biomass is often coupled with an increase in soil microbial richness and diversity (Burns et al., 2013; Sinsabaugh et al., 2017).

We observed a significant reduction in soil microbial biomass, respiration, dehydrogenase and urease activities following invasive species removal, but this response was attenuated when the invasive plant species were left intact in comparison with the control. Our results suggest that care must be taken when large scale removal of invasive dominant plant species is planned to restore natural vegetation. In South Africa, removal to protect water resources and native biodiversity led to significant soil loss through erosion even 11 years after the removal event (van der Waal et al., 2012). The observed alterations in microbial biomass, respiration and enzyme activities may have long-term consequences on stable soil $\mathrm{C}$ and $\mathrm{N}$ pools. Reductions in total $\mathrm{C}$ pools were observed in Microstegium invaded forest sites due to rapid decline in mobile $\mathrm{C}$ pools (Strickland et al., 2011). Differences in soil $\mathrm{C}$ and $\mathrm{N}$ pools between invasive plant species removed and unremoved sites have the potential to impact soil microbial respiration and activities that are critical for soil $\mathrm{C}$ stabilization (Anderson and Domsch, 2010; Hagerty et al., 2014).

\subsection{Soil microbial indices as ecological indicators}

Soil microorganisms need more energy to support their growth demand (catabolism) and biomass production (anabolism), i.e., they utilize the substrate less efficient under disturbed or stressed conditions (Anderson and Domsch, 2010). Higher MBC/SOC and lower $q \mathrm{CO}_{2}$ values at $C S$ and PUS and AUS compared to their respective removed sites show that natural and undisturbed ecosystems maintain more organic matter in the soil, allowing for a higher MBC content per unit of soil C (Murugan et al., 2014a; Spohn, 2015). At both study locations, increased $q \mathrm{CO}_{2}$ and decreased $\mathrm{MBC} / \mathrm{SOC}$ ratio indicate that more energy is spent toward catabolic needs at the expense of anabolic needs due to the disturbance caused by Prosopis and Acacia removal. The observed negative correlation between the $q \mathrm{CO}_{2}$ and soil $\mathrm{pH}$ ( $r=-0.44, P<0.01, n=60$ ) indicates that microbial communities released more $\mathrm{CO}_{2}-\mathrm{C}$ per unit microbial biomass under low soil pH conditions at PRS and ARS (Anderson and Domsch, 1993). In support of our fourth hypothesis, high $q \mathrm{CO}_{2}$ values in soil at PRS and ARS indicate that MBC pools declined at a faster rate than $S O C$, resulting in a drop in the $\mathrm{MBC} / \mathrm{SOC}$ ratio, a pattern that is commonly observed under stress conditions (Anderson and Domsch, 2010; Hagerty et al., 2014). A possible explanation is that allelopathic phenolic compounds released by invasive plant species roots and litter might have increased microbial activity (Kaur et al., 2012; Inderjit and Cahill, 2015), which consequently increased $q \mathrm{CO}_{2}$ compared to local vegetation. The loss of soil moisture possibly due to increased soil temperature after removal of Prosopis might be another driving factor. This was supported by the fact that soil moisture showed a positive relationship with the $\mathrm{MBC} / \mathrm{SOC}$ ratio $(r=0.69, P<0.01, n=$ 36) and a negative relationship with $q \mathrm{CO}_{2}(r=-0.84, P<0.01$, $n=36$ ). In a recent global meta-analysis, positive relationships between soil temperature and $q \mathrm{CO}_{2}$ have been attributed to shifts in microbial community composition toward communities with faster turnover rates and increased activity of microbial predators (Hagerty et al., 2014; Spohn, 2015).

The MBC/MBN ratio increased with increasing plant diversity due an increase in functional groups rich in lignin (trees, saplings, shrubs), as shown by the $64 \%$ and $20 \%$ higher MBC/MBN ratios observed at the species rich CS and PRS compared to species poor PUS. Changes in substrate inputs via litter and roots under diverse vegetation might have promoted microorganisms with slower turnover rates (Anderson and Domsch, 2010; Hagerty et al., 2014; Spohn, 2015). Also changes in the availability of nutrients, especially a reduction in $\mathrm{P}$ availability result in higher $\mathrm{MBC} / \mathrm{MBN}$ ratios (Salamanca et al., 2006; Khan et al., 2016). The dominance of fungal biomass and residues has been negatively correlated with $q \mathrm{CO}_{2}$ in both managed and natural ecosystems (Murugan et al., 2013, 2014a). Although, MBC/SOC and $q \mathrm{CO}_{2}$ cannot discriminate between disturbed or stressed (e.g. nutrient poor) ecosystems but together serves as valuable indices for soil quality (Anderson and Domsch, 2010; Wardle and Ghani, 2018). Our results indicate that the interaction between above and belowground communities is a critical factor determining the structure and dynamics of local plant communities (Inderjit and van der Putten, 2010; Bardgett et al., 2013), especially in ecosystems affected by plant invasions (Inderjit and Cahill, 2015).

\section{Conclusions}

Our results show that the removal of dominant invasive plant species led to an increase in the local plant diversity and ground vegetation cover through reduced competition for resources. Removal of Prosopis and Acacia resulted in a decline in SOC and total $\mathrm{N}$ due to enhanced microbial respiration and $\mathrm{N}$ mineralisation rates. Loss of plant canopy enhanced mineralisation of SOM and suppressed microbial biomass and enzyme activities indicate a decline in soil quality. High $q \mathrm{CO}_{2}$ in soil at PRS and ARS indicate that 
microbial $\mathrm{C}$ pools declined at a faster rate than $\mathrm{SOC}$, resulting in a drop in MBC/SOC ratio due to stress caused by plant removal and presence of allelopathic phenolic compounds released by invasive plant species roots and litter. Though we examined the magnitude of Prosopis and Acacia invasion and subsequent removal on local plant diversity, ecosystem processes such as basal respiration, $\mathrm{N}$ mineralisation rate, enzyme activities and soil ecological indicators, uncertainty remains as to how long these observed results may persist. As soil $\mathrm{C}$ and $\mathrm{N}$ pools and microbial activity decline following invasive plant species removal, the re-establishment of local vegetation might still be prevented by invasive plant legacy effects via changes in soil and litter chemistry (Ehrenfeld, 2010). Therefore, experiments that evaluate the effects of invasive species removal on environmental conditions and the re-colonisation of local plant species are essential for determining whether invader-dominated sites are beyond the threshold for practical restoration or whether management actions can succeed in reverse back to the historical conditions of these unique ecosystems.

\section{Acknowledgements}

We thank the Tamil Nadu Forest Department, India for funding and permissions to conduct this study. We thank our field team from the Indo American Wildlife Society (Dr. C. Arivazhagan, Dr. B. Ramakrishnan, Dr. P. Santhoshkumar, Mr. S. Karthick, and Mr. A. Samson) for their support during field work. Technical assistance of Gabriele Dormann is highly appreciated. We acknowledge the kind English revision done by Dr. Isabella Bertani.

\section{Authors' contributions}

RM, NP and RGJ conceived the ideas and designed the methodology; RM and SM carried out the laboratory work and NP carried out the field; FB, NP and SM analyzed the data; RM and FB led the writing of the manuscript. All authors contributed critically to the drafts and gave final approval for publication.

\section{Conflict of interest}

The authors have declared that no competing interest exists.

\section{References}

Ali, R., 2005. Field Studies for the Conservation and Management of Point Calimere Complex. A technical report for the Tamil Nadu Forest Department. FERAL, Pondicherry. https://www.feralindia. org/drupal/sites/default/files/ptcalfinaltechrep.pdf

Anderson, T.H., Domsch, K.H., 1993. The metabolic quotient for $\mathrm{CO}_{2}$ $\left(q \mathrm{CO}_{2}\right)$ as a specific activity parameter to assess the effects of environmental conditions, such as $\mathrm{pH}$, on the microbial biomass of forest soils. Soil Biology \& Biochemistry 25, 393-395.

Anderson, T.H., Domsch, K.H., 2010. Soil microbial biomass: the eco- physiological approach. Soil Biology \& Biochemistry 42, 2039 2043.

Arasumani, M., Khan, D., Das, A., Lockwood, I., Stewart, R., Kiran, R. A., Muthukumar, M., Bunyan, M., Robin, V.V., 2018. Not seeing the grass for the trees: Timber plantations and agriculture shrink tropical montane grassland by two-thirds over four decades in the Palani Hills, a Western Ghats Sky Island. PLoS One 13, e0190003.

Bardgett, R.D., Manning, P., Morrien, E., De Vries, F.T., 2013. Hierarchical responses of plant-soil interactions to climate change: consequences for the global $\mathrm{C}$ cycle. Journal of Ecology 101, 334-343.

Baskaran, N., Ramkumaran, K., Karthikeyan, G., 2016. Spatial and dietary overlap between blackbuck (Antilope cervicapra) and feral horse (Equus caballus) at Point Calimere Wildlife Sanctuary, Southern India: Competition between native versus introduced species. Mammalian Biology-Zeitschrift für Säugetierkunde 81, 295-302.

Beck, T., Joergensen, R.G., Kandeler, E., Makeschin, F., Nuss, E., Oberholzer, H.R., Scheu, S., 1997. An inter-laboratory comparison of ten different ways of measuring soil microbial biomass $\mathrm{C}$. Soil Biology \& Biochemistry 29, 1023-1032.

Brookes, P.C., Landman, A., Pruden, G., Jenkinson, D.S., 1985. Chloroform fumigation and the release of soil nitrogen: a rapid direct extraction method to measure microbial biomass nitrogen in soil. Soil Biology \& Biochemistry 17, 837-842.

Burns, R.G., DeForest, J.L., Marxsen, J., Sinsabaugh, R.L., Stromberger, M.E., Wallenstein, M.D., Weintraub, M.N., Zoppini, A., 2013. Soil enzymes in a changing environment: current knowledge and future directions. Soil Biology \& Biochemistry 58, 216-234.

Callaway, R.M., Aschehoug, E.T., 2000. Invasive plants versus their new and old neighbors: a mechanism for exotic invasion. Science 290, 521-523.

Caner, L., Seen, D.L., Gunnell, Y., Ramesh, B.R., Bourgeon, G., 2007. Spatial heterogeneity of land cover response to climatic change in the Nilgiri highlands (southern India) since the Last Glacial Maximum. Holocene 17, 195-205.

Casida, L.E. Jr, Klein, D.A., Santoro, T., 1964. Soil dehydrogenase activity. Soil Science 98, 371-376.

Chazdon, R.L., 2003. Tropical forest recovery: legacies of human impact and natural disturbances. Perspectives in Plant Ecology, Evolution and Systematics 6, 51-71.

Courchamp, F., Caut, S., Bonnaud, E., Bourgeois, K., Angulo, E., Watari, Y., 2011. Eradication of alien invasive species: surprise effects and conservation successes. Pages 285-289. In: Veitch, C. R., Towns, D. R. (eds.) Island Invasives: Eradication and Management. IUCN, Gland, Switzerland.

Cutway, H.B., 2017. Effects of Long-Term Manual Invasive Plant Removal on Forest Understory Composition. Natural Areas Journal 37, 530-539.

Daubenmire, R., 1959. A canopy-coverage method of vegetational analysis. Northwest Science 33, 43-64.

Ehrenfeld, J.G., 2010. Ecosystem consequences of biological invasions. Annual Review of Ecology Evolution and Systematics 41, 59-80.

Goenster, S., Grundler, C., Buerkert, A., Joergensen, R.G., 2017. Soil 
microbial indicators across land use types in the river oasis Bulgan sum center, Western Mongolia. Ecological Indicators 76, 111-118.

Hagerty, S.B., Van Groenigen, K.J., Allison, S.D., Hungate, B.A., Schwartz, E., Koch, G.W., Kolka, R.K., Dijkstra, P., 2014. Accelerated microbial turnover but constant growth efficiency with warming in soil. Nature Climate Change 4, 903-906.

Inderjit, CahillJ.F., 2015. Linkages of plant-soil feedbacks and underlying invasion mechanisms. AoB Plants 7, plv022.

Inderjit, W.H., van der Putten, 2010. Impacts of soil microbial communities on exotic plant invasions. Trends in Ecology \& Evolution 25, 512-519.

Inderjit, C., Catford, J.A., Kalisz, S., Simberloff, D., Wardle, D.A., 2017. A framework for understanding human-driven vegetation change. Oikos 126, 1687-1698.

Janssens, I., Dieleman, W., Luyssaert, S., Subke, J.A., Reichstein, M., Ceulemans, R., Ciais, P., Dolman, A.J., Grace, J., Matteucci, G., Papale, D., Piao, S.L., Schulze, E.D., Tang, J., Law, B.E., 2010. Reduction of forest soil respiration in response to nitrogen deposition. Nature Geoscience 3, 315-322.

Joshi, A.A., Sankaran, M., Ratnam, J., 2018. 'Foresting'thegrass-land: Historical management legacies in forest-grassland mo-saics in southern India, and lessons for the conservation of tropi-cal grassy biomes Biological Conservation 224, 144-152.

Kandeler, E., Gerber, H., 1988. Short-term assay of soil urease activity using colorimetric determination of ammonium. Biology and Fertility of Soils 6, 68-72.

Kaur, R., Gonzáles, W.L., Llambi, L.D., Soriano, P.J., Callaway, R.M., Rout, M.E., Gallaher, T.J., Inderjit, 2012. Community impacts of Prosopis juliflora invasion: biogeographic and congeneric comparisons. PLoS One 7, e44966.

Khan, K.S., Mack, R., Castillo, X., Kaiser, M., Joergensen, R.G., 2016. Microbial biomass, fungal and bacterial residues, and their relationships to the soil organic matter C/N/P/S ratios. Geoderma 271, 115-123.

Levine, J.M., Vilà, M., D’Antonio, C.M., Dukes, J.S., Grigulis, K., Lavorel, S., 2003. Mechanisms underlying the impacts of exotic plant invasions. Proceedings. Biological Sciences 270, 775-781.

Liang, C., Balser, T.C., 2011. Microbial production of recalcitrant organic matter in global soils: implications for productivity and climate policy. Nature Reviews. Microbiology 9, 75, author reply 75.

Liao, C., Peng, R., Luo, Y., Zhou, X., Wu, X., Fang, C., Chen, J., Li, B., 2008. Altered ecosystem carbon and nitrogen cycles by plant invasion: a meta-analysis. New Phytologist 177, 706-714.

Lorenzo, P., Rodrigues-Pereira, S., Rodríguez-Echeverría, S., 2013. Differential impact on soil microbes of allelopathic compounds released by the invasive Acacia dealbata Link. Soil Biology \& Biochemistry 57, 156-163.

Love, A., Babu, S., Babu, C.R., 2009. Management of Lantana, an invasive alien weed, in forest ecosystems of India. Current Science 97, 1421-1429.

Marchante, E., Kjøller, A., Struwe, S., Freitas, H., 2008. Short- and long-term impacts of Acacia longifolia invasion on the belowground processes of a Mediterranean coastal dune ecosystem. Applied Soil Ecology 40, 210-217.

Murugan, R., Beggi, F., Kumar, S., 2014b. Belowground carbon allocation by trees, understory vegetation and soil type alter microbial community composition and nutrient cycling in tropical Eucalyptus plantations. Soil Biology \& Biochemistry 76, 257-267.

Murugan, R., Koch, H.J., Joergensen, R.G., 2013. Long-term influence of tillage intensities on soil microbial biomass, residues and community structure at different depths. Biology and Fertility of Soils $50,487-498$.

Murugan, R., Loges, R., Taube, F., Sradnick, A., Joergensen, R.G., 2014a. Changes in soil microbial biomass and residual indices as ecological indicators of land use change in temperate permanent grassland. Microbial Ecology 67, 907-918.

Nehru, P., Balasubramanium, P., 2014. Recovery rate of vegetation in the tsunami impacted littoral forest of Nicobar Islands. India. Forest Ecology and Management 313, 243-253.

Peet, R.K., Wentworth, T.R., White, P.S., 1998. A flexible, multipurpose method for recording vegetation composition and structure. Castanea 63, 262-274.

Pyšek, P., Jarošík, V., Hulme, P.E., Pergl, J., Hejda, M., Schaffner, U., Vilà, M., 2012. A global assessment of invasive plant impacts on resident species, communities and ecosystems: the interaction of impact measures, invading species' traits and environment. Global Change Biology 18, 1725-1737.

Salamanca, E.F., Raubuch, M., Joergensen, R.G., 2006. Microbial reaction of secondary tropical forest soils to the addition of leaf litter. Applied Soil Ecology 31, 53-61.

Seigler, D.S., 2003. Phytochemistry of Acacia sensu lato. Biochemical Systematics and Ecology 31, 845-873.

Sharma, G.P., Raghubanshi, A.S., 2009. Lantana invasion alters soil nitrogen pools and processes in the tropical dry deciduous forest of India. Applied Soil Ecology 42, 134-140.

Simberloff, D., Martin, J.L., Genovesi, P., Maris, V., Wardle, D.A., Aronson, J., Courchamp, F., Galil, B., García-Berthou, E., Pascal, M., Pyšek, P., Sousa, R., Tabacchi, E., Vilà, M., 2013. Impacts of biological invasions: what's what and the way forward. Trends in Ecology \& Evolution 28, 58-66.

Sinsabaugh, R.L., Moorhead, D.L., Xu, X., Litvak, M.E., 2017. Plant, microbial and ecosystem carbon use efficiencies interact to stabilize microbial growth as a fraction of gross primary production. New Phytologist 214, 1518-1526.

Spohn, M., 2015. Microbial respiration per unit microbial biomass depends on litter layer carbon-to-nitrogen ratio. Biogeosci 12, 817823.

Stone, M.M., Deforest, J.L., Plante, A.F., 2014. Changes in extracellular enzyme activity and microbial community structure with soil depth at the Luquillo Critical Zone Observatory. Soil Biology \& Biochemistry 75, 237-247.

Strickland, M.S., DeVore, J.L., Maerz, J.C., Bradford, M.A., 2011. Loss of faster-cycling soil carbon pools following grass invasion across multiple forest sites. Soil Biology \& Biochemistry 43, 452- 454.

Van der Waal, B.W., Rowntree, K.M., Radloff, S.E., 2012. The effect of Acacia mearnsii invasion and clearing on soil loss in the Kouga Mountains, Eastern Cape, South Africa. Land Degradation \& Development 23, 577-585.

van Kleunen, M., Dawson, W., Essl, F., Pergl, J., Winter, M., Weber, E., Kreft, H., Weigelt, P., Kartesz, J., Nishino, M., Antonova, L.A., 
Barcelona, J.F., Cabezas, F.J., Cárdenas, D., Cárdenas-Toro, J., Castaño, N., Chacón, E., Chatelain, C., Ebel, A.L., Figueiredo, E., Fuentes, N., Groom, Q.J., Henderson, L., Inderjit, A., Kupriyanov, S., Masciadri, J., Meerman, O., Morozova, D., Moser, D.L., Nickrent, A., Patzelt, P.B., Pelser, M.P., Baptiste, M., Poopath, M., Schulze, H., Seebens, W.S., Shu, J., Thomas, M., Velayos, J. J., Wieringa, P., Pyšek, 2015. Global exchange and accumulation of non-native plants. Nature 525, 100-103.

Vance, E.D., Brookes, P.C., Jenkinson, D.S., 1987. An extraction method for measuring soil microbial biomass carbon. Soil Biology \& Biochemistry 19, 703-707.

Wardle, D.A., Ghani, A., 2018. A tale of two theories, a chronosequence and a bioindicator of soil quality. Soil Biology \& Biochemistry 121, A3-A7.

Wu, J., Joergensen, R.G., Pommerening, B., Chaussod, R., Brookes, P.C., 1990. Measurement of soil microbial biomass $C$ by fumigation-extraction - an automated procedure. Soil Biology \& Biochemistry 22, 1167-1169. 